\section{Copper-Catalyzed Asymmetric Nucleophilic Addition to Ketones}

\section{Category}

Metal-Catalyzed Asymmetric

Synthesis and

Stereoselective

Reactions

\section{Key words}

copper catalysis

asymmetric reaction

1,2-addition

silane reagents

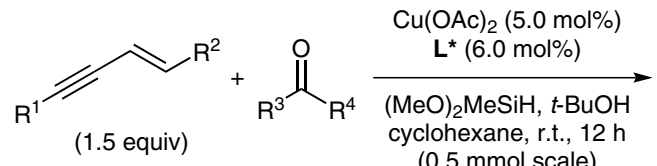

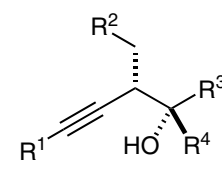
35 examples $45-95 \%$ yield 90-99.5\% ee up to $d r>10: 1$

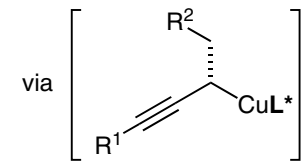

Selected examples:<smiles>C[C@H](C#Cc1ccccc1)[C@](C)(O)c1ccccc1</smiles>

$86 \%$ yield $\mathrm{dr}=10: 1$ $96 \%$ ee<smiles>CC(C#Cc1ccccc1)C(O)(c1ccccc1)c1ccccc1</smiles>
$71 \%$ yield $92 \%$ ee<smiles>C[C@H](C#Cc1ccccc1)[C@](C)(O)c1ccc(C(F)(F)F)cc1</smiles>

$88 \%$ yield $\mathrm{dr}=10: 1$ $99 \%$ ee<smiles>C[C@H](C#Cc1ccsc1)[C@](C)(O)c1ccccc1</smiles>

$86 \%$ yield $\mathrm{dr}=10: 1$
$96 \%$ ee<smiles>C[C@H](C#Cc1ccccc1)[C@](C)(O)c1cccc(Br)c1</smiles>

$93 \%$ yield $\mathrm{dr}>10: 1$ $99 \%$ ee

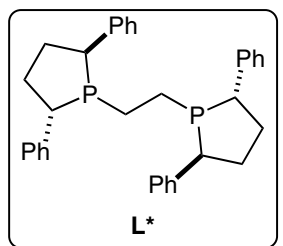

13 Gram scale reaction and derivatizations:<smiles></smiles>

$65 \%$ yield $97 \%$ ee<smiles>Cc1nn(-c2ccc([C@](C)(O)[C@H](C)C#Cc3ccccc3)cc2)c(C)c1Br</smiles><smiles>C[C@@H](C#Cc1ccccc1)[C@](C)(O)c1ccc(C(F)(F)F)cc1</smiles>

(13 gram scale, $0.2 \mathrm{~mol} \%$ cat. purified by recrystallization

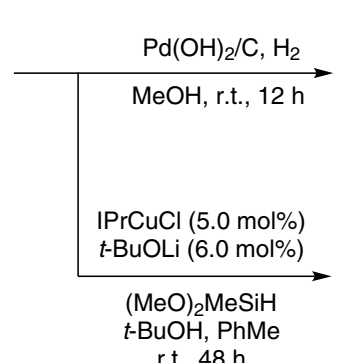

r.t. $48 \mathrm{~h}$<smiles>C[C@H](CCc1ccccc1)[C@](C)(O)c1ccc(C(F)(F)F)cc1</smiles><smiles>C[C@H](/C=C\c1ccccc1)C(C)(C)c1ccc(C(F)(F)F)cc1</smiles>

Significance: Enantioenriched alcohols represent a recurring structural motif in biologically active molecules and pharmaceuticals. The synthesis of this class of compounds usually relies on the addition of nucleophiles to carbonyl compounds. The limitations of this approach in terms of functionalgroup tolerance and versatility prompted the authors to develop a novel copper-catalyzed asymmetric addition of nucleophiles, generated in situ from olefins, to ketones.

SYNFACTS Contributors: Mark Lautens, Ivan Franzoni Synfacts 2016, 12(09), 0923 Published online: 18.08.2016 Dol: 10.1055/s-0035-1561902; Reg-No.: L08516SF
Comment: A chiral copper catalyst promoted the reaction between a number of enyne substrates with ketones. $(\mathrm{MeO})_{2} \mathrm{MeSiH}$ and $t-\mathrm{BuOH}$ are required to generate the nucleophile in situ and to terminate the catalytic cycle, respectively. The reaction delivers the corresponding chiral alcohols in good yields and excellent enantioselectivities. A 13 gram scale reaction, derivatizations of the final products and applications in the synthesis of pharmaceutical agents were provided. Furthermore, computational studies were carried out to explain the observed enantio- and diastereoselectivity. 